\title{
LA CONSTRUCCIÓN DE LOS DISCURSOS POÉTICOS Y MUSICALES EN LA ESPAÑA DE 1900 A 1936. RELACIONES Y DIVERGENCIAS INTERDISCIPLINARES
}

\author{
JUAN Gómez ESPINOSA \\ UNED \\ jotacalera@hotmail.com
}

\section{RESUMEN}

La creación española en las tres primeras décadas del siglo XX se movió desde las posiciones más ortodoxas con la tradición artística a las de sesgo radicalmente rupturista. Buscar las correspondencias entre las labores de compositores y poetas de aquellos años puede ofrecernos varias perspectivas enriquecedoras para la investigación: analizar y comprender mejor herramientas y enfoques creativos de una época tan heterogénea como brillante, establecer puentes entre los discursos poéticos y sonoros, ahondar en el difícil y ambiguo diálogo existente entre neocasticismo y neopopularismo... Para ello, es necesario abordar figuras como Falla o Lorca, Alberti, Albéniz, los Halffter, los zarzuelistas, Machado... así como sus producciones, no de manera aislada sino en plena interacción de unos con otros y con la realidad socio-política que vivieron.

Palabras Clave: Poesía española; Música española; Siglo XX; Vanguardia; Literatura comparada.

\section{Abstract}

The artistic Spanish creation in the first three decades of the twentieth century moved from the most orthodox positions with artistic tradition to radically disruptive routes. Searching correspondences between the work of composers and poets of those years can offer several enriching perspectives for research: analyze and understand better tools and creative approaches in such as bright as heterogeneous time, build bridges between the poetic 
and sonorous speeches delving into the difficult and ambiguous existing dialogue between neocasticismo and neopopulism ... To do taht, it is necessary to tackle figures like Falla or Lorca, Alberti, Albeniz, the Halffters, the zarzuelistas, Machado ... and their productions and not in isolation but in full interaction with others and with the socio-political reality that lived about.

KeY WORDS: Spanish Poetry; Spanish Music; 20th Century; Vanguard; Comparative Literature.

\section{INTRODUCCIÓN}

En las siguientes páginas mostraré las correspondencias discursivas existentes entre creación poética y musical en la España de 1900 a 1936. Aunque la práctica de ambas disciplinas ya estuviera, en aquella época, mucho más separadas que en siglos anteriores, los recursos utilizados tanto por compositores como por poetas mantienen una serie de vínculos que señalaré en el presente artículo. Al hablar de vínculo, no me refiero a las eventuales uniones surgidas de colaboraciones entre artistas sonoros y literarios, las cuales se inscriben dentro de sus trayectorias profesionales o afectivas. Este estudio se centra en la esencia de la creación, es decir, en la construcción de los discursos poéticos y musicales, ateniéndose a los recursos técnicos compartidos.

Una época como la elegida ofrece una amplísima variedad de manifestaciones y sensibilidades. Para facilitar el análisis del asunto en tal contexto, propongo una distinción entre tres perspectivas creadoras que exponen, a su vez, el rico e intenso debate artístico del momento, resumido en la dialéctica tradición/modernidad o, lo que es lo mismo, perspectiva conservadora, por un lado, y rupturista y progresista, por el otro, según la radicalidad de planteamientos novedosos.

\section{CONTEXTO HISTÓRICO Y PERSPECTIVAS ARTÍSTICAS DE LA CREACIÓN}

Una época convulsa trae aparejados debates convulsos en todos sus parámetros: desde la política a la administración, desde el pensamiento al arte. La España del primer tercio del siglo XX fue un ejemplo de constante replanteamiento de la realidad. En tres décadas y media, el país experimentó tres cambios de régimen político, cada uno de ellos sometido a diversos vaivenes internos; y el año 36 traería, como todos sabemos, un golpe de estado de consecuencias bien conocidas. Un tiempo y un lugar, por lo tanto, marcados por la convulsión, y más si se tiene en cuenta que esta se enmarca en una crisis internacional de la cual la Primera Guerra Mundial es la muestra más evidente (pero no la única). La heterogeneidad procedente de un contexto así puede resultar una herramienta muy valiosa para analizar en profundidad, con variedad de ópticas y ejemplos, el debate artístico del momento.

La compleja dialéctica que protagonizan en aquellos años todos los ámbitos del país no puede dejar de resumirse como la eterna discusión entre pasado y futuro: qué debe mantenerse de la herencia recibida y qué debe desecharse. Las circunstancias de la época dan 
como resultado de este debate tres posturas o perspectivas: una conservadora, empeñada en salvaguardar las estructuras tradicionales; otra, frente a ella, rupturista, convencida de que solo echando abajo los elementos heredados se puede labrar con eficacia el presente (y, por lo tanto, el futuro); y una tercera a medio camino de las mencionadas, de carácter progresista, puesto que busca con ahínco el avance pero no renuncia partir de elementos anteriores. Las tres perspectivas observan toda la realidad del momento, aunque en el caso de este estudio nos interesa, ante todo, cómo abordan la labor artística.

Analizando las diferentes perspectivas en lo referente a poesía y música españolas de la época, podemos bucear en un hecho más íntimo de ambas disciplinas: los rasgos comunes que definen la construcción de sus discursos. La primitiva unión de poesía y música en torno a la canción, que las convierte en disciplinas dependientes del desarrollo y la organización temporales (Kramer, 1984), fue resquebrajándose desde la irrupción de la imprenta y sus efectos sobre la transmisión oral (McLuhan, 1962); en torno al siglo XIX, el hermanamiento sería herido mortalmente con el individualismo romántico y la progresiva alfabetización de las sociedades más avanzadas impulsando la lectura solitaria y personal. No obstante, la antiquísima práctica común que aunaba creación poética y musical puede seguir rastreándose, incluso en la obra de autores solo productores de una de las dos artes; una hermandad con tantos siglos de tradición a sus espaldas no puede borrarse fácilmente, al fin y al cabo. A este respecto, es imprescindible el impulso dado desde los años 60 por los estudios de Brown (1963), Tarasti (1979) o Barricelli (1988), entre otros, centrados en análisis de base lingüística que ahondan en las correspondencias poético-musicales; por ejemplo, en los efectos de repetición y variación, la carga semántica o la naturaleza del estribillo (Luján, 2010).

Por nuestra parte, en la presente exposición analizaremos la creación poética y musical en el intenso contexto ya citado, la España de 1900 a 1936, para buscar en sus objetos artísticos los elementos discursivos comunes a ambas artes. Partiremos, además, de las tres perspectivas ya comentadas, puesto que se corresponden con las necesidades anímicas y las inquietudes expresivas de los autores contemporáneos.

\section{MANTENIMIENTO DE LOS RECURSOS DISCURSIVOS TRADICIONALES}

En rigor, no puede decirse que la óptica conservadora nazca, en aquel momento de la historia nacional, de estímulo alguno. Esto se debe a que su seña identificativa es, justamente, la continuidad; continuidad con los elementos heredados. Los autores conservadores no pretenden romper la cadena histórica del devenir artístico, ni trastocar sus eslabones. Reforzarlos, por supuesto. Darles nuevo brillo, también. Esto no significa que carezcan absolutamente de espíritu crítico y por fuerza pequen de inmovilistas. Los debates dentro de la misma perspectiva serán continuos. De hecho, entre la materia heredada se encontrarán con discusiones finiseculares de largo alcance.

En el terreno poético, una de las más importantes será la sostenida, hacia 1891, entre Campoamor y Valera en torno a la preeminencia de lo útil o lo bello en la poesía (Rivas Hernández, 2008: 136-146); el otro gran debate en este ámbito sería el que mantuvieron Núñez de Arce y Clarín sobre la influencia del naturalismo en el terreno poético y los límites entre 
verso y prosa (Navas Ruiz, 2010:49). En el mundo musical, la gran batalla de finales del XIX fue la librada entre partidarios y detractores del wagnerianismo. Todas estas discusiones llegarían hasta los albores del nuevo siglo, condicionando la labor creadora. A raíz de un debate como el entablado entre Núñez de Arce y Clarín, se va perfilando un campo de batalla estético que plantearía sus principal cuestión acerca del tono literario y la forma.

A partir de la discusión entre Campoamor y Valera, se desprendería una dualidad en el lenguaje poético conservador del siglo XX: por un lado, un tipo preciosista, esteta, sugerente, y por otro uno mucho más realista y sencillo. El primero procede de la segunda oleada romántica decimonónica, marcadamente trascendental, ansiosa de musicalidad y ritmo junto a sensualidad en el verso. Estos ecos románticos, unidos a la influencia francesa simbolista, parnasiana y decadentista, desembocarán en el desarrollo del modernismo hispánico. Esta corriente literaria tiene un papel paradójico al poco de andar el siglo XX; si bien en 1900 da frutos tan importantes e innovadores como La copa del rey de Thule, de Villaespesa, Ninfeas y Almas de Violeta, de Juan Ramón Jiménez, Odas, de Marquina, Flor de escarcha, de Martínez Sierra o Alma andaluza, de Sánchez Rodríguez, para 1907 ya es percibido por el público como algo totalmente normalizado (Celma, 1993: 25-38). Del Olmo y Díaz fechan la efervescencia del movimiento entre 1900 y 1909 (2008:28). A partir de entonces, ya empezará a mostrarse manido y en decadencia. Por lo tanto, el modernismo, que tan fresco había resultado para el panorama poético del último cuarto decimonónico —más allá de si su pilar fundacional se halla en Rubén Darío o Salvador Rueda (Cardwell, 2008: 21-47)—, se fue tornando cada vez menos moderno según avanzaba la primera década del XX. El otro tipo de lenguaje poético conservador, de sesgo más sencillo y realista, tuvo como principales cultivadores a los autores regeneracionistas del 98 , más interesados en el mensaje ofrecido que en la belleza de su forma.

No obstante, limitar la nómina de poetas conservadores a modernistas y noventayochistas se acercaría peligrosamente al reduccionismo. Una amplísima cantidad de literatos camparán en esta perspectiva, ya sea identificándose con los virtuosos y sensuales modernistas, ya con los más austeros noventayochistas, ya manteniendo ecos románticos (aquí podemos encontrar incluso al joven Gerardo Diego del Romancero de la novia) o apostando por la identidad nacional tradicionalista en cualquiera de sus vertientes (por ejemplo, casticista).

El panorama musical conservador también estará condicionado por los debates heredados. Así, la sofisticación germana supondrá un síntoma de prestigio, pese a que esa influencia pivote principalmente sobre los nombres de Wagner y Brahms (muertos en 1883 y 1897 , respectivamente). No obstante, el romanticismo sonoro todavía tiene en pie, en aquella época, campeones de la talla de Richard Strauss. Estas influencias se pueden apreciar en compositores como Conrado del Campo o Julio Gómez, o tantos contemporáneos suyos que buscan la creación no solo de un firme repertorio camerístico, sino de un sinfonismo hispánico, así como de una ópera nacional, lo que sí habían conseguido sus modelos románticos internacionales. Esta búsqueda se realizó con grandísimo esfuerzo, no siempre recompensado justamente. Esto no puede extrañarnos si somos conscientes de que la coyuntura musical propiamente española, en cuanto a medios de difusión e interpretación, demostró estar plagada de carencias y dificultades en el paso de un siglo a otro. Poco a poco, sin embargo, las primeras décadas vieron nacer gradualmente formaciones e instituciones 
que permitieron ir alcanzado cierta firmeza en la ejecución y divulgación musical (Marco, 1998: 26-27). Junto a esta práctica compositiva de alta sofisticación, los músicos españoles también practicarán, y con mayor éxito, un repertorio más ligero, arraigado en la pintura costumbrista nacional, y que tiene en la zarzuela su más celebrado exponente. Algo aparte de este circuito profano, no podemos olvidar todo un movimiento creador enfocado hacia la música religiosa: la llamada Generación del «Motu Proprio», impulsada por la encíclica homónima de Pío X de 1903, y que buscaba el desarrollo del repertorio vinculado a la Iglesia. El tipo de lenguaje utilizado por estos compositores se encontraba arraigado en un conservadurismo que pretendía combinar la tradición gregoriana con el estilo decimonónico. Pese a la escasa audacia de este tipo de obras, este movimiento se mantuvo activo hasta el Concilio Vaticano II.

Tanto poetas como compositores conservadores pretenden, pues, mantener la herencia creadora, lo cual supone recurrir a sistemas constructivos también heredados. Esto se traduce en el uso de estructuras anteriores. En poesía, por lo tanto, se utilizará la métrica tradicional, con todo lo que ello conlleva (estrofas, pies rítmicos, cláusulas...), y en la disciplina sonora formas musicales como la sonata o la canción. Incluso las novedades aportadas entrarán dentro del fluir natural de la historia artística. Los experimentos versificadores de los modernistas no son sino hijos de la polimetría y ambiciosa inquietud romántica. Incluso el audaz Rueda había demostrado su respeto a las formas y estrofas antiguas, pero abogando a la vez por refrescarlas, renovarlas en cuanto a ritmo, léxico y estructura (Rueda, 1894: 61). De la misma manera, las construcciones más libres de los compositores siguen la tradición del poema sinfónico o la fantasía, que tanto predicamento habían tenido en el siglo anterior. A los creadores conservadores no les interesa tanto utilizar una forma específica u otra como el hecho de marcar con unas pautas fijas sus discursos; estas pautas, obviamente, tienen sus cimientos en la tradición. Un poema tan aparentemente libre como pueda ser el escrito según cláusulas rítmicas no deja de ser un objeto artístico articulado a partir de una pauta que se torna normativa; y esas cláusulas, en definitiva, se asientan en los pies rítmicos de los que parten los metros más antiguos.

En la disposición del texto literario o sonoro —es decir, en la sintaxis y la semántica para la poesía, y en el comportamiento melódico y armónico para la música一, estos autores se comportarán de manera semejante. Los poetas no romperán el orden sintáctico, ni apostarán por el ilogicismo y el irracionalismo en los significados del texto (más allá de alguna que otra imagen sensual o fantasmagórica heredada del simbolismo). Los compositores, no renunciarán al sistema tonal más académico y convencional. El resultado es que las obras de unos y otros no escaparán a los efectos que el público general asimila sin dificultad. Y así, a través de una disposición textual convencional, unida a estructuras poéticas ortodoxas con la tradición, los creadores conservadores podrán hacerse entender con claridad, ya sea movidos por una inquietud de sesgo modernista, romántica, regeneracionista, casticista...

En el siguiente fragmento del poema «A orillas del Duero», proveniente de Campos de Castilla (1917), Antonio Machado viste su panorámica nacional con pautas semánticas y estructurales absolutamente tradicionales; ni rastro de expresiones ilógicas (más bien al contrario: el aliento es directo y reflexivo), y un mensaje que queda solemnizado por el largo aliento del alejandrino: 
[...]El Duero cruza el corazón de roble

de Iberia y de Castilla.

¡Oh, tierra triste y noble,

la de los altos llanos y yermos y roquedas,

de campos sin arados, regatos ni arboledas;

decrépitas ciudades, caminos sin mesones,

y atónitos palurdos sin danzas ni canciones

que aún van, abandonando el mortecino hogar,

como tus largos ríos, Castilla, hacia la mar! [...] (Machado, 1973: 82)

La apelación a la identidad nacional desde el campo sonoro puede reflejarse perfectamente en unos compases como los que siguen, pertenecientes a la zarzuela de Moreno Torroba Luisa Fernanda (1932), marcados por un respeto al sistema tonal tradicional (el fluido armónico, basado en triadas convencionales, y melódico se asienta sobre Re Mayor, aunque con alguna flexión hacia el relativo menor) y, además, la imitación de aire popular:
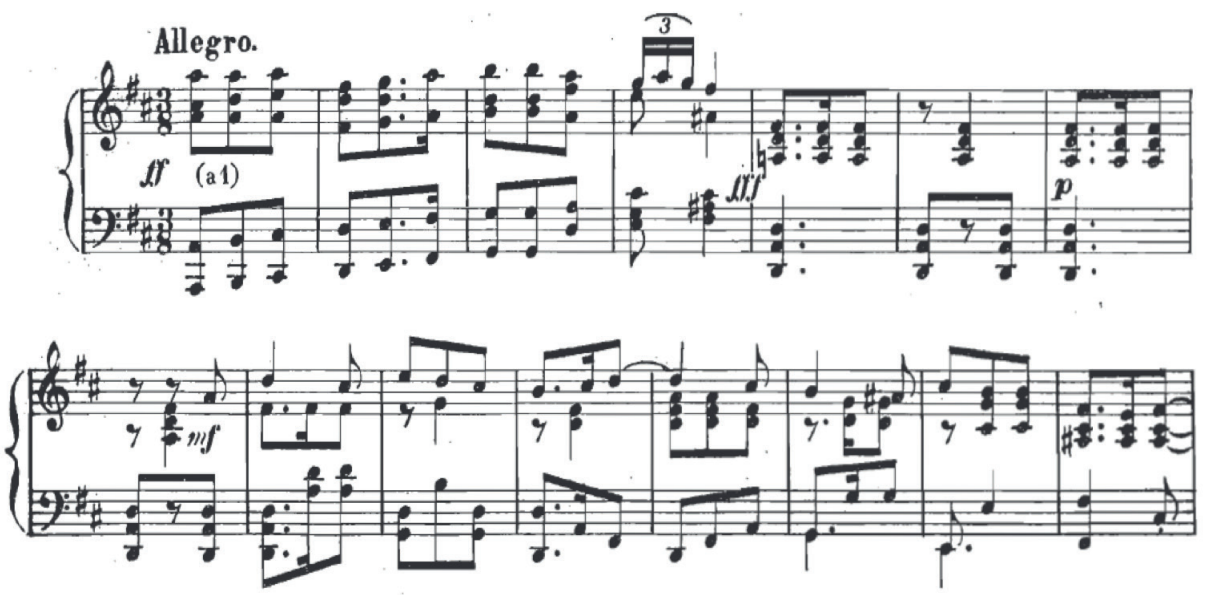

Moreno Torroba, 1932: 101.

Por su lado, el joven Gerardo Diego expone sin ambages la naturaleza romántica de su Romancero de la novia:

[...]Ahora vivo solo y triste

y desahogo mis nervios

en estos versos románticos

que me sirven de consuelo [...] (Diego, 1995: 51)

Aliento romántico que se mantiene, por ejemplo, en el Cuarteto en Re (1922) de Tomás Bretón; de nuevo, respeto absoluto al fluir armónico y melódico tonal junto a extroversión 
sentimental, coloreada por la inclusión de floreos, apoyaturas y notas de paso a distancia de semitono que nunca llegan a hacer ambigua la tonalidad principal:

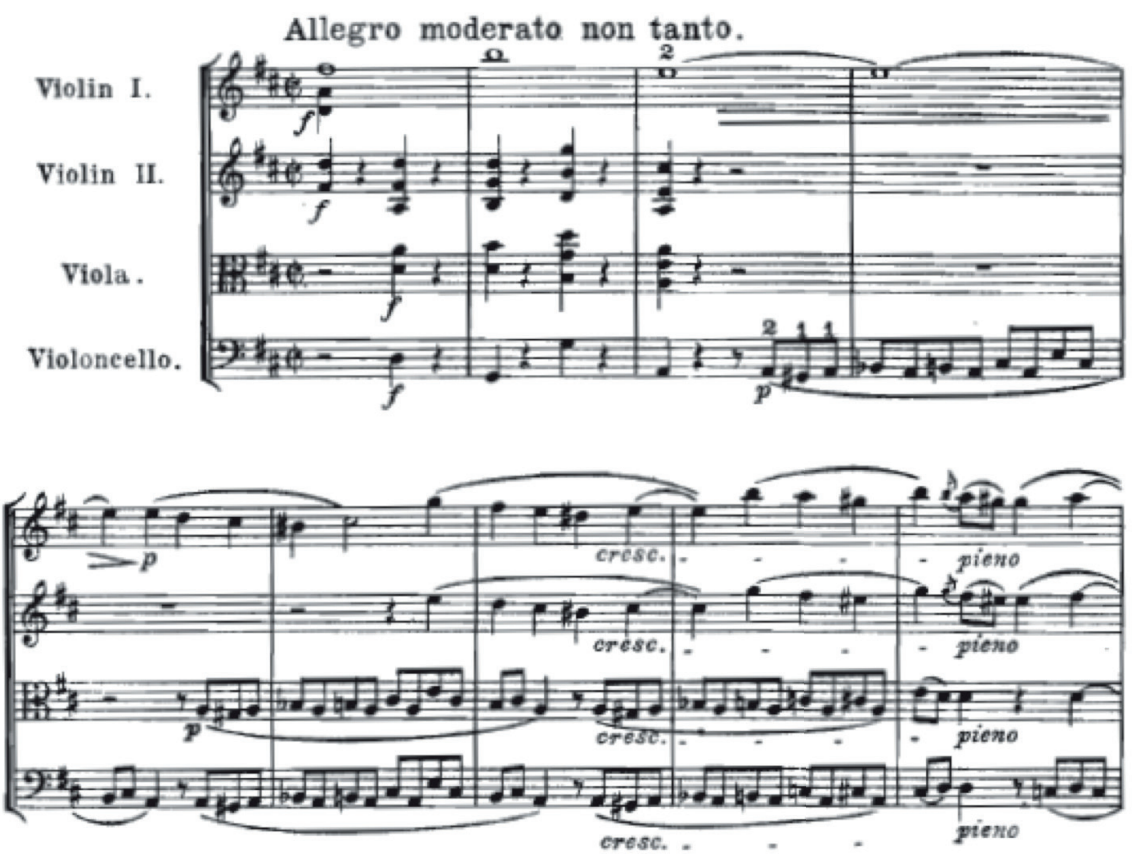

Bretón, 1920: 1.

Los recursos convencionales (dicho esto sin intención peyorativa) de poetas y músicos conservadores facilitó que el arte surgido de esta perspectiva fuera el más difundido y exitoso de la época.

\section{BÚSQUEDA RADICAL DE NUEVAS TÉCNICAS EXPRESIVAS}

Al otro lado del conservadurismo, se alza su némesis. La perspectiva rupturista ve en la óptica anterior inmovilismo o, al menos, una serie de estructuras que ya no tienen cabida en un mundo nuevo, sometido a constantes cambios y a una crisis mundial en todos los ámbitos; crisis que o bien los elementos heredados han causado o no han podido solucionar.

Frente a la necesidad de pautas asentadas en la tradición, los autores rupturistas apuestan por la novedad y, sobre todo, por la libertad a la hora de construir sus discursos. Más allá de dogmatismos en los que pueda caer una proposición concreta, subyace el deseo de no basar los objetos artísticos en los cimientos del pasado. A nuevos tiempos, nuevas formas de crear. Incluso se pide que esas nuevas formas, a ser posible, no sean sacralizadas como tales. Las disposiciones anímicas y afectivas de la época ya no se pueden plasmar según las disposiciones artísticas convencionales. De ahí que el lenguaje, musical y poético, deba ser trastocado. En el mundo literario, lo irracional, lo ilógico y la imagen audaz e inesperada conformarán el 
aliento de la ruptura. En la poesía española, la permeabilidad a las corrientes vanguardistas del momento será inmediata, llegando a brillar con luz propia en el ultraísmo, el creacionismo y la influencia del surrealismo, aunque la ortodoxia de esta en el panorama nacional se someta a diversas discusiones, como en el caso que ilustran las palabras de Lorca en torno a los poemas de su Poeta en Nueva York: «No es surrealismo, jojo!, la conciencia más clara los ilumina» (García Lorca, 1968: 1654). Unos versos del poeta granadino perteneciente al citado libro reflejan conexiones semánticas radicalmente sorprendentes, turbadoras e irracionales, en unos metros bien alejados de los convencionales:

$$
\begin{aligned}
& \text { [...]Uno } \\
& \text { y uno } \\
& \text { y uno. }
\end{aligned}
$$

Estaban los tres momificados, con las moscas del invierno, con los tinteros que orina el perro y desprecia el vilano, con la brisa que hiela el corazón de todas las madres, por los blancos derribos de Júpiter donde meriendan muerte los borrachos [...] (García Lorca, 1987: 118).

A la novedosa y valiente disposición del texto poético le corresponde en música la renuncia a la tonalidad. Dicha renuncia jalona la obra de un nutrido y variado grupo de compositores del momento (desde la Segunda Escuela de Viena hasta los experimentos de Charles Ives en Estados Unidos o Edgar Varese en Francia, pasando por el nuevo y místico mundo sonoro de la última etapa de Skryabin en Rusia, entre otros). Sin embargo, apenas encontramos muestras de música rupturista entre los compositores españoles de la época. La atonalidad es prácticamente inexistente en la composición española anterior a la guerra, y menos aún la práctica dodecafónica (Charles, 2005). El paso hacia la atonalidad solo lo dan unos pocos músicos nacionales, y ni siquiera lo utilizan íntegramente en sus obras, sino en pequeños fragmentos (así, por ejemplo, Salvador Bacarisse en Heraldos o Rodolfo Halffter en Naturaleza Muerta). Incluso Roberto Gerhard, tan íntimamente ligado a Arnold Schoenberg, abrazaría la práctica atonal con toda firmeza después de la Guerra Civil. En España, por lo tanto, no se alumbró en el ámbito musical la miríada de posibilidades que conllevaba la caída de la tonalidad más allá de nuestras fronteras, no pudiéndose hacer extensibles a la realidad nacional las siguientes palabras:

Un radical y agresivamente nuevo tipo de música requirió la brutal destrucción de los hábitos que se habían establecido durante el largo e ininterrumpido reino de la tonalidad tradicional. Visto desde un punto de vista positivo, la caída de la tonalidad permitió la llegada de un momento de extraordinaria liberación y relajo, que hizo posible un estado, aparentementeilimitado, de posibilidades que anteriormente hubieran resultado inimaginables (Morgan, 1999: 32).

En el panorama compositivo español de entonces, no encontraremos la radicalidad ni la agresividad destructiva que tanto marcaban las vanguardias literarias. En resumen, unos compases como los siguientes, pertenecientes al Pierrot Lunaire (1912) de Arnold Schoenberg, construidos a partir de la ruptura con la tonalidad, las armonías convencionales y los fraseos melódicos predecibles: 


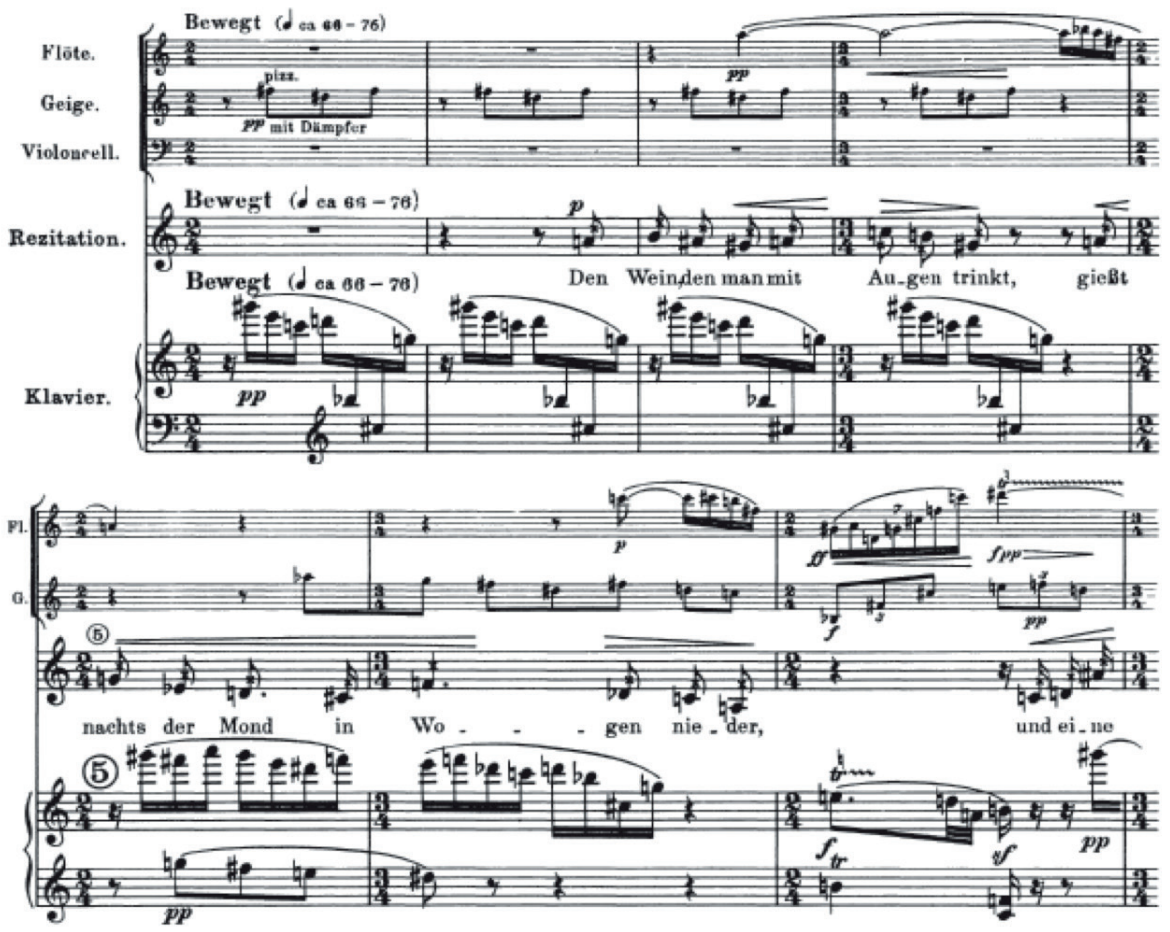

Schoenberg, 1914: 1 .

Por lo tanto, en lo que a la perspectiva rupturista se refiere, no se puede hallar una extensa correspondencia entre creación poética y musical en la España de la época. Realmente, en este sentido, es justo decir que la literatura jugaba con ventaja con respecto a la composición. Sin ser en absoluto sencillo el camino que la poesía rupturista tuvo que abrirse en el contexto nacional, lo cierto es que la difusión de la palabra escrita gozaba de mayores medios que la de la música. Si ya resultó complicado intentar ponerse a la altura de Europa en cuanto a formaciones musicales fijas y sólidas se refiere, más difícil todavía fue conseguir interpretar y mostrar realidades sonoras de presupuestos tan radicales. Habría que esperar todavía a la etapa de la posguerra para que los propios compositores asimilaran bien las tendencias más audaces y alejadas de la tradición.

\section{EL EQUILIBRIO ENTRE LAS ESTRUCTURAS ARTÍSTICAS HEREDADAS Y LA MODERNIDAD}

Encontrarse a medio camino de las otras dos ópticas no significa que la progresista resulte tibia, ni mucho menos. De hecho, el no alinearse ni con conservadores ni con rupturistas la puede someter a críticas por parte de ambos bandos. Este tipo de perspectiva está honestamente interesada en el avance artístico, huye del inmovilismo tradicionalista, pero 
no desprecia cuanto puede ayudarle de lo heredado para impulsarse hacia el futuro. Los creadores progresistas de la época, por lo tanto, recogerán para sus discursos procedimientos estructurales de la tradición. Los músicos no van a dejar de componer para géneros y formas con tanta historia a sus espaldas como el concierto, la sonata, la canción, la ópera o el ballet. De la misma manera, los poetas siempre utilizarán formas tradicionales, desde el soneto hasta las provenientes de la lírica popular. En este sentido, autores de una u otra disciplina podrán elegir entre estructuras más o menos libres.

En el terreno de la poesía, nos referimos a estrofas o tiradas de versos como las cuartetas asonantadas o la silva libre, de gran flexibilidad pero, no obstante, bien pautada, y que ha sido analizada con tanto acierto por Navarro Tomás (1995), Isabel Paraíso (1985) o Domíguez Caparrós (2007 y 2014). Tampoco podemos olvidar, al enfrentarnos con estrofas de aparente libertad estructural, las certeras palabras de Díez de Revenga abordando buena parte de la métrica en los poetas del 27:

«[...]no debemos, pues, considerar verso libre aquel que tiene como bases fundamentales los elementos rítmicos tradicionales aunque en ocasiones, leves y momentáneamente, abandone el paradigma a que venía ajustándose« (Díez de Revenga, 1973: 274).

La mirada de los creadores progresistas siempre estará puesta en la cadena de la historia artística. Es significativo cómo muchos de los escritores aprovecharán el amplio margen de la ya citada tirada de cuartetas asonantadas, que no implica un límite de extensión, para dar rienda suelta a su plasmación del mundo con una sensibilidad propia del momento, o cómo apostarán en otras ocasiones por el caso contrario: poemas de extensión mínima, entre la cancioncilla popular y el haiku. Los compositores, por su parte, alternarán sin problema entre piezas formadas según los moldes tradicionales más estrictos y otras de construcción más libre (heredadas, a su vez, de formas anteriores como el preludio o la fantasía).

Al mantener las formas heredadas, también se mantienen otros elementos fuertemente ligados a ellas. En la poesía: la rima o su ausencia dependiendo de su papel en estructuras tradicionales, las cláusulas o pies métricos, la regularidad en el número de sílabas de los versos... En la música, la tonalidad, como garante de discursos que fluyen en la dialéctica tensión/distensión. De esta manera, tanto el verso como el sonido conservarán efectos que el público medio tiene perfectamente asimilados. Este detalle no deja de tener su trascendencia desde el punto de vista de la percepción, ya que se trata de una época en la que los productos artísticos rupturistas podían llegar a actuar contra la rítmica esperada en un poema o la sonoridad de una pieza.

Sin embargo, si todos estos creadores buscaran la mera recepción, fluida y total, por parte del público, estarían demostrando un convencionalismo difícilmente concordante con sus intenciones de avance. No necesitarían más que dejarlo todo tal cual. Su gran aportación viene, justamente, de la audacia con la que se movieron para renovar lo heredado y adaptarlo a las inquietudes de un mundo tan complejo. Aunque las formas - y todo lo que suponense mantengan, en la disposición de los elementos lingüísticos — literarios y musicales- es donde llevarán a cabo sus acciones definitivas estos autores. Los poetas van a dar de lado, por una parte, el lenguaje vehementemente sentimental, sometido a virtuosismos extravertidos en muchas ocasiones, de modernistas y románticos epigonales; por otra parte, también se alejarán del anecdotismo, el didactismo y el realismo (que a veces se traduce en casticista o legendaria 
interpretación de la identidad nacional) planteados por regeneracionistas y tradicionalistas. La música progresista también escapará tanto de los efluvios románticos como de la simple reproducción sonora de aires populares. Ni los unos ni los otros, sin embargo, llegarán a dinamitar los materiales heredados con la misma radicalidad que los rupturistas, aunque compartirán con estos la búsqueda de una nueva expresividad, más ligada al sentir personal que a un repertorio de efectos consensuado. El punto de unión de todos los creadores progresistas radicará en el anti-retoricismo o anti-academicismo, si entendemos lo académico o retoricista del momento como un abanico de pautas, formales y expresivas, convencionales a fuerza de trilladas. Los poetas no romperán con la sintaxis tradicional, ni caerán en sentidos herméticos a la manera de tantos rupturistas; pero tampoco abrazarán de los conservadores las altisonancias sentimentales, el colorismo virtuosista, el tópico pseudo-folklórico, la seca exposición de la realidad...

Los músicos seguirán partiendo del sistema tonal para desarrollar sus obras, pero lo someterán a procesos y efectos novedosos alejados de las técnicas compositivas más tradicionales. Así, no será raro encontrar en las nuevas piezas armonías que no se ajustan totalmente a la triada convencional y sus enlaces, ambigüedades tonales, flujos melódicos de comportamientos inesperados (por ejemplo, frases musicales interrumpidas súbitamente o moduladas hacia colores sorprendentes), disonancias que replantean el debate sobre lo bello y agradable en el arte... Los siguientes compases de los Cants mágics (1919) de Frederic Mompou son prueba de todo lo dicho; sobre un soporte tonal que recuerda a Mi bemol y una base que bebe de la técnica del pasacalle, el autor desarrolla unas sonoridades imprevisibles, apoyado en armonías y movimientos de voces que huyen de la ortodoxia tradicional:
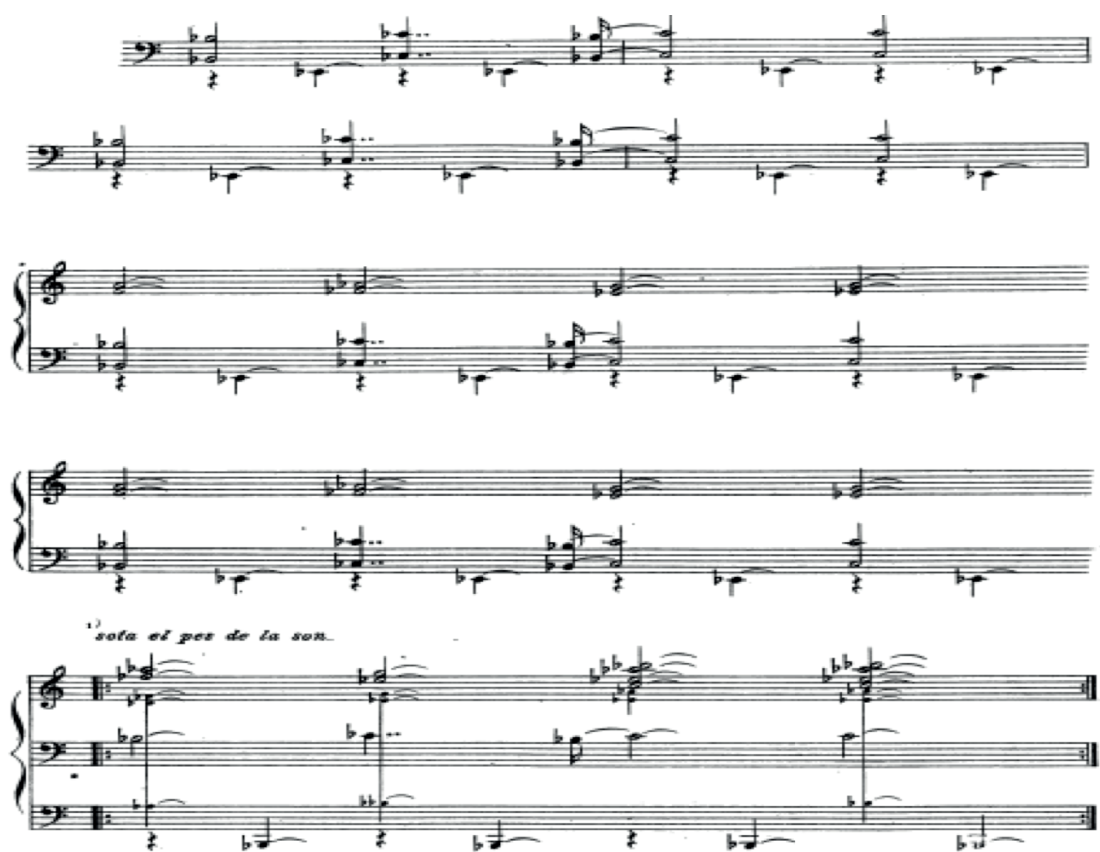

Mompou, 1920: 6. 
En su actitud anti-convencional los artistas progresistas tienen su punto de unión, pero en cuanto a la praxis, jugarán con varias vías de actuación para dar vida a sus obras. Los diferentes caminos podrán transitarse de manera aislada o complementándose unos con otros, lo cual es síntoma de las múltiples opciones que barajaban los autores, buenos conocedores de la tradición pero también permeables a las últimas corrientes creativas internacionales.

Una de las vías principales la constituyó la del despojamiento o purificación discursiva. La tendencia hacia el despojamiento fue una de las improntas fundamentales en la creación no conservadora, y actuó en contra del prosaísmo, anecdotismo y didactismo realista, y la grandilocuencia, exaltación, virtuosismo extravertido y/o retoricismo romántico y modernista.

El término «puro« plantea dos problemas: por un lado, ha sido utilizado comúnmente para hablar del ámbito poético; sin embargo, por la apuesta semejante a favor de un discurso despojado de superficialidades que también siguen los compositores, en esta exposición lo emplearemos también para la producción musical. Por otro lado, en la época se llegó a considerar «pura « toda poesía no tradicional, fuera progresista o rupturista, como bien se desprende de los testimonios recogidos en el estudio de Cano Ballesta (1972). En el presente análisis, entenderemos como «puro« sólo aquel tipo de creación de carácter progresista, no rupturista, que busca el despojamiento expresivo a partir de elementos tradicionales.

En la poesía, la brecha abierta por Juan Ramón, sobre todo a partir de Estío (1916), fue continuada autores más jóvenes como Salinas, Guillén, los primeros poemarios de Cernuda y Aleixandre, o María Cegarra, entre otros. En todos ellos, asistimos a un análisis de la realidad en la cual el individuo busca la comunión armoniosa con el universo entero, pero sin esgrimir un tono vehemente y abigarrado, como bien demuestra uno de los primeros poemas de Luis Cernuda:

Existo, bien lo sé,

Porque le transparenta

El mundo a mis sentidos

$\mathrm{Su}$ amorosa presencia.

Mas no quiero estos muros,

Aire infiel a mí mismo,

$\mathrm{Ni}$ esas ramas de cantan

En el aire dormido.

Quiero como horizonte

Para mi muda gloria

Tus brazos, que ciñendo

Mi vida la deshojan [...] (Cernuda, 2006: 111).

La aparente sencillez de los discursos puede encerrar una compleja profundidad en el análisis de la relación entre un ser humano y el resto de los seres. La concisión es la norma 
general en este tipo de poemas, que giran en torno a unos mínimos elementos y pueden llegar a tomar una forma brevísima. La economía de medios expresivos también se convirtió en norma para la creación musical progresista, huyendo así de la efusividad romántica. Los motivos melódicos parcos en alturas, las células rítmicas repetitivas, así como estructuras que en absoluto recuerdan las densidades de sesgo conservador y académico, se van desarrollando como norma compositiva de Manuel de Falla desde poco antes de su marcha hacia París en 1907 (lo cual ya se comprueba, por ejemplo, en sus Cuatro piezas españolas comenzadas en 1906), y que eclosionaría en todo su esplendor con El amor brujo (1915). En la «Danza ritual del fuego«, de esa misma obra, la repetición de elementos rítmicos y melódicos mínimos, la ambigüedad de un flujo sonoro imprevisible (comenzado por el misterio del doble trino a distancia de semitono que marca los primeros veintitrés compases, desarrollado por las conexiones entre los tonos de La menor, Do menor, las disonancias o choques entre Mi bemol y Mi natural...), desarrollan un discurso que poco tiene que ver con la más absoluta convención tradicional:

Allo ma non troppo. $(\mathbf{M} . d=126)$
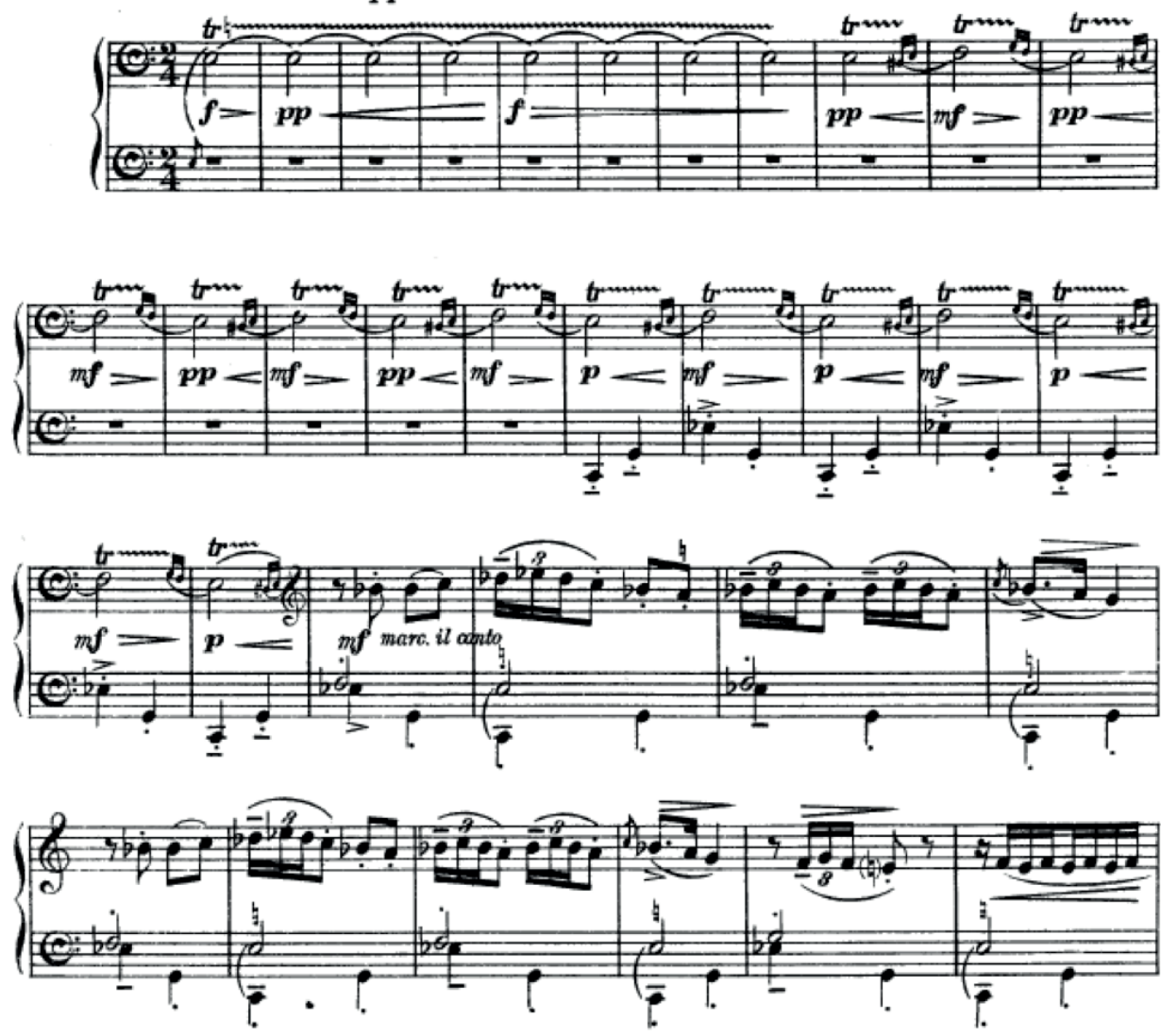

(Falla, 1924: 16). 
Esta purificación del discurso musical será adoptada también por tantos y tantos músicos jóvenes, discípulos suyos espirituales o reales (como los Halffter). Pero el despojamiento en esta disciplina no solo afectará a la parte más técnica de la elaboración discursiva, sino también a su espíritu. Al igual que la poesía pura desechará la sentimentalidad vehemente en su expresión, la música tampoco apostará por la plasmación exaltada. Poetas y compositores evitarán una excesiva implicación con el objeto artístico que los someta y condicione. La búsqueda del tono preciso pasará por elaboraciones y reelaboraciones intensas. Prueba de ello son las reescrituras juanramonianas de su obra o la correspondencia intercambiada entre Falla y algunos músicos más jóvenes, anhelantes de los consejos del maestro, profundamente expuesta por Yvan Nommik (2002: 41-70).

En las antípodas aparentes de la purificación expresiva, pero dentro de la perspectiva progresista, podemos encontrar también una vía de «impureza«, en la cual el autor no tenga reparos en mostrar dramatismo en su expresión. En el terreno poético, se ha asociado el término «poesía impura« con una producción influida por la Primera Residencia en la Tierra nerudiana (publicada íntegramente por vez primera en España, en 1935, aunque algunos de sus poemas ya habían sido difundidos con antelación, como en la Revista de Occidente, en el número de marzo de 1930). Pese a que el poemario del chileno se ajusta mucho más, por su expresividad irracional y libertad formal, a la perspectiva rupturista, poetas progresistas como Miguel Hernández no dudaron en seguir su espíritu torturado y complejo (muy alejado de la comunión cósmica de los poetas puros), pero sin llegar a caer en el hermetismo vanguardista y recurriendo a estrofas tradicionales como el soneto; en este, se respeta el cauce formal del soneto, pero el léxico esgrimido está caracterizado por una mezcla de vehemencia, imprevisibilidad y abstracción :

¿No cesará este rayo que me habita

el corazón de exasperadas fieras

y de fraguas coléricas y herreras

donde el metal más fresco se marchita?

¿No cesará esta terca estalactita

de cultivar sus duras cabelleras

como espadas y rígidas hogueras

hacia mi corazón que muge y grita?

Este rayo ni cesa ni se agota:

de mí mismo tomó su procedencia

y ejercita en mí mismo sus furores.

Esta obstinada piedra de mí brota

y sobre mí dirige la insistencia

de sus lluviosos rayos destructores (Hernández, 2005: 130)

No obstante, la impureza en el discurso poético la podemos rastrear antes del vendaval nerudiano. Así, la pintura grotesca de La pipa de Kif (1919) o de buena parte de los poemas 
de su gran admirador, Mauricio Bacarisse. La música tampoco escapó a la eventual expresión más dramática. Aunque no se aupó como tendencia principal, el juego con el sistema sonoro tradicional, al que se malea hasta la ambigüedad, puede alcanzar altas cotas de oscuridad, como en el caso del Cuarteto con piano de Fernando Remacha (1933), o de empuje irrefrenable, como en estos compases con los que Ernesto Halffter cierra su Danza de la gitana (1927):
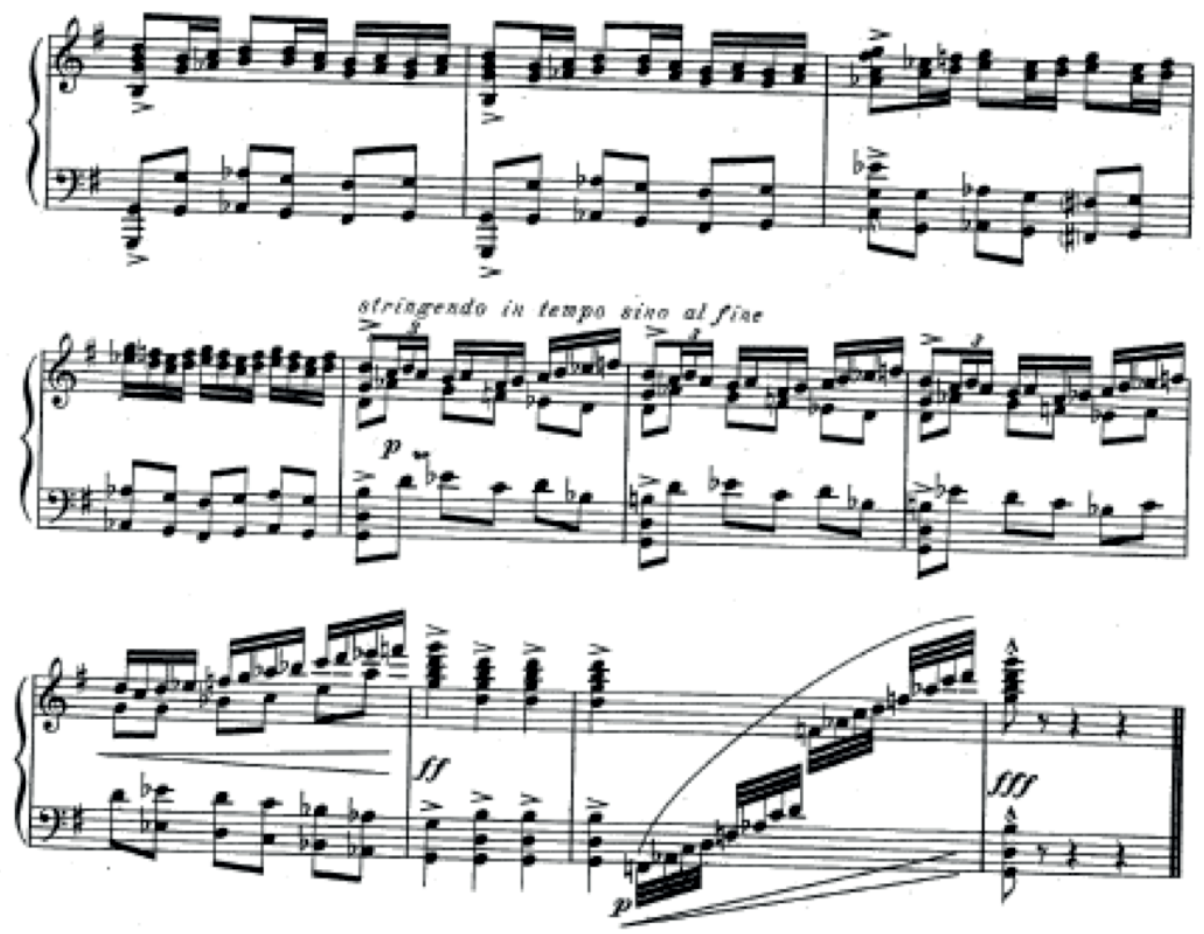

Halffter, 1927: 8.

Otra vía sería la que gira en torno al material histórico. Mientras que el conservadurismo buscaba en el pasado el refuerzo y la justificación de señas de identidad — políticas, ideológicas o artísticas - que pretendía mantener, la visión progresista intentará aprovechar de otros tiempos recursos con los que poder impulsarse hacia delante. Lo que se recupere del pasado será mezclado con la sensibilidad inquieta y multiforme del siglo XX. Como bien afirmaba Octavio Paz:

«Lo viejo de milenios también puede acceder a la modernidad: basta con que se presente como una negación de la tradición y que nos proponga otra. Ungido por los mismos poderes polémicos que lo nuevo, lo antiquísimo no es un pasado: es un comienzo» (Paz, 1974: 19).

Esta tendencia estaría íntimamente ligada a la purificadora, ya que hablar de pureza, orden y despojamiento se corresponde perfectamente con el neoclasicismo impulsado, una vez acabada la Primera Guerra Mundial, desde Francia por el grupo de Los Seis (cuyos miembros, a 
su vez, tenían como padres espirituales a Satie, un compositor de lenguaje radicalmente puro, y Cocteau). Esta influencia fue clave para numerosos compositores españoles, especialmente los comúnmente señalados bajo los membretes de Grupo de los Ocho (madrileño) y Grupo de los Cinco (barcelonés). Entre estos músicos se halla un predicamento neoclásico muy significativo, con piezas que remiten a este gusto por la sencillez expresiva y estructuras heredadas del orden clásico. Pero también, cómo no, nutre obras de la figura magistral de aquellos años: Falla. La economía de medios y la austeridad caracterizan El retablo de maese Pedro (1923) y el Concierto para clave y cinco instrumentos (1926) en las que, además de la sombra dieciochesca de Scarlatti, se atiende también a otra época del pasado: los Siglos de Oro. Y, justamente, hacia aquella edad de brillo literario miran tantos escritores, a mediados de la década de 1920 y de los 30 (siendo las celebraciones de los tricentenarios de Góngora y Lope de Vega, respectivamente, referencias fundamentales para todo un grupo de poetas). A este respecto, al igual que en música los comportamientos melódicos y armónicos se revisten con estructuras heredadas del pasado más brillante, en la poesía las imágenes novedosas se adaptan a formas asociadas a los Siglos de Oro, como vemos en Cernuda (Égloga, elegía, oda), Diego (Fábula de Exis y Zeda) o Lorca (Oda al Santísimo Sacramento).

Por último, la vía que ahonda en el material folklórico o popular cobrará un papel clave en la creación progresista del momento. Aunque la recuperación de la voz, anónima y colectiva, de un pueblo ya había sido característica romántica, los autores progresistas actuarán de manera semejante a la labor emprendida con el material histórico. Nada tendrá que ver el aprovechamiento de este ámbito con la plasmación (o cuestionamiento) de identidades nacionales propias de la perspectiva conservadora. La flexibilidad de las construcciones folklóricas, tan alejada de lo académico, será una herramienta de lo más favorable para los inquietos autores. El anisosilabismo, así como cierto misterio y ambigüedad de tantas imágenes de las cancioncillas populares, serán aprovechados por los poetas, mientras que los músicos harán lo propio con los ritmos y las cadencias de la música folklórica. El material popular, además, se mezclaba armoniosamente con el histórico, tanto por sus orígenes en la niebla del pasado, como por sus conexiones con autores cultos. De ahí las palabras de Dámaso Alonso:

Participamos ampliamente en un momento - anterior ya a nosotros, pero que nosotros fomentamos grandemente:- el gusto por la poesía popular y por las canciones populares. A un mismo tiempo, traíamos hasta el público el entusiasmo por Gil Vicente, tan entrañado en la popularidad medieval, y rehabilitábamos la memoria de un don Luis de Góngora, cima de artificiosa aristocracia (Alonso, 1962: 62).

Y todo ello, unido a disposiciones audaces de ambos lenguajes artísticos (ambigüedad, formulaciones enigmáticas, sinestesia o, directamente, misterio e irracionalismo poéticos, armonías y movimientos melódicos poco convencionales). Entre los compositores, una vez más, la figura de Manuel de Falla se alzaría como maestro, directo o espiritual, en este uso universalista del elemento popular (al unir material folklórico con hallazgos técnicos de lo más avanzado en la Europa del momento). Sin embargo, no podemos olvidar que junto a él, o incluso antes, hubo otros compositores que también ayudaron a abrir esta vía en el terreno musical. Por ejemplo, el Albéniz último de la Suite Iberia, o Esplá y Turina (aunque el popularismo de este fuera tornando tipismo andalucista conservador con los años). Aquí vemos, 
pues, una diferencia profunda entre los creadores progresistas y conservadores: mientras que estos recurren al material popular para reflejar identidades nacionales (con mayor o menor realismo, ya que pueden tender en ocasiones a lo legendario o idealizado), los primeros se sirven de él para explorar nuevos territorios creativos, y todo en un contexto de apasionante debate entre pasado y futuro. La siguiente composición de Alberti, perteneciente a El alba del alhelí (1927), hunde sus raíces en el cancionero popular en la forma (metros oscilantes entre las ocho y cinco sílabas, rima asonante, estribillo), y en el fondo su enigmático imaginario une tanto la ambigüedad de la lírica antigua como los cauces irracionales aprovechados por la modernidad; las citadas piezas de Falla o Halffter, con su aprovechamiento de ritmos y sonoridades folklóricas y, a la vez, con un estiramiento o apertura de las posibilidades tonales, podrían hermanarse con estos versos:

Una mano, solo una,

por entre los terciopelos,

para regar los claveles.

¿Por qué no quieres

que yo te vea la cara?

¿Para qué tanto esconderte

y siempre esa mano sola,

como una mano cortada,

para regar los claveles?

¿Por qué no quieres

que yo te vea la cara? (Alberti, 1988: 254)

Dicho de otra manera: la manera de utilizar el material folklórico por parte de los creadores progresistas daría lugar al neopopularismo, mientras que la praxis conservadora en este sentido podría ser tildada de neocasticismo.

De todas estas vías transitadas por los autores progresistas se trasluce, por un lado, su afán por el avance de la creación artística, pero también su profunda formación, no solo pendiente de las novedades de la época, sino también del aprovechamiento del material tradicional. Esta perspectiva no llega a plegarse a la norma conservadora de respeto absoluto a la linealidad histórica, pero tampoco renuncia a la herencia artística como los rupturistas, ni ensaya nada absolutamente nuevo. Sí que malea el material encontrado y lo estira, a veces hasta quedarse a las puertas de su demolición. A la vista de esta actitud, nunca radical pero siempre anhelante de progreso, no es de extrañar que la inmensa mayoría de estos autores se relacionara, más o menos directamente, con la Institución Libre de Enseñanza. Esta afirmación no se sostiene solo por las acciones pedagógicas y culturales que auspició (por la Residencia de Estudiantes pasó, por ejemplo, lo más granado de la cultura nacional e internacional, e incluso compositores como Ravel, Milhaud, Poulenc o Strawinsky actuaron en ella). La razón es mucho más profunda, y obedece al ámbito ideológico: el krausismo siempre obró con afán progresista, pero respetando a su vez el sistema imperante (aunque pretendiera, a la 
larga, reformarlo). Ya Sanz del Río, el gran impulsor del krausismo español, exponía entre sus principios esenciales:

«En historia, respetamos la verdad de los hecho, y los apreciamos según las reglas de la moral y del derecho, para que sirvan de enseñanza a las generaciones presentes, sin comprimir la marcha libre y progresiva de la sociedad» (Sanz del Río, 1867: 427).

El aprecio «según las reglas de la moral y el derecho« acepta cierta herencia de valores, con la cual la sociedad puede ser reformada de manera «progresiva», pero no tras una ruptura. Tal como señala Tuñón de Lara:

«Los institucionistas no son revolucionarios, en el sentido habitual del término; muchos de ellos piensan [...] que la transformación será posible dentro del sistema» (Tuñón de Lara, $1970: 45)$.

Los autores de la perspectiva progresista actuaron siempre con un pie apoyado en los sistemas heredados y el otro bien dispuesto hacia el futuro, característica evidente de la influencia de la Institución.

\section{CONCLUSIONES}

Esta exposición se ha vertebrado a partir de tres perspectivas artísticas que hemos propuesto como herramienta metodológica: una conservadora, una progresista y una rupturista, lo cual puede ayudar a un análisis riguroso de la creación en el contexto elegido. Sin embargo, tomar demasiado en serio cualquier tipo de estructura puede hacernos caer en un reduccionismo nada deseable. Creo humildemente que el esquema tridimensional propuesto es una herramienta eficaz, pero no puedo permitir que caiga en el olvido una verdad obvia: el arte da cuenta de cómo un individuo actúa frente a los estímulos de la realidad, de su realidad. Tomar partido por una perspectiva u otra es natural, ya que recogen el abanico posible de actitudes anímicas y sociales. Sin embargo, un ser humano es multidimensional, y puede mudar de actitud dependiendo de la coyuntura. Esto, como decía al comienzo, no tiene por qué ser señal de falta de principios. La dialéctica no solo actúa en la Gran Historia, sino también en la más íntima, individual. La creación en el marco geográfico y temporal analizado da numerosos ejemplos de dinamismo y heterogeneidad personales. Así, Gerardo Diego fue capaz de caminar por las tres perspectivas estéticas sin merma alguna de calidad, elaborando poemarios más conservadores o más avanzados siempre con coherencia interna. Afirmaciones semejantes se pueden dar de la labor de Lorca, Alberti, Aleixandre, - Valle que pasó de la ambientación rural de Aromas de leyenda (1907) a los ecos modernistas de El Pasajero (1920) - y la estética más progresista de La Pipa de Kif (1919), Lasso de la Vega (que saltó del modernismo a la vanguardia) y tantos otros.

Tampoco podemos caer en la tentación de pensar que a una perspectiva artística le tenga que corresponder una ideológica concreta. Antonio Machado, sincero poeta de estética tradicional, demostró un pensamiento político abiertamente progresista, mientras que Falla, que fue desarrollando una producción gradualmente progresista, nunca dejó de abrazar postulados religiosos, sociales y políticos conservadores. Hablar de posibles perspectivas artísticas 
podría servirnos, por encima de cualquier otra cuestión, para poder analizar profundamente al ser humano que es el creador, individuo que se responsabiliza de su expresión porque así afronta su realidad. En su dialéctica interior puede experimentar cambios de óptica, unas veces voluntarios y otras no, pero siempre significativos. Este planteamiento puede ser de interés a la hora de estudiar la trayectoria de un autor, y conlleva tanta amplitud de matices como la propia de cada personalidad individual.

El foco de este trabajo, sin embargo, apunta ante todo a las semejanzas de procedimientos, expresivos y técnicos, entre creadores musicales y poéticos en el contexto espacio-temporal especificado. Tras este análisis multidisciplinar, se puede afirmar que poetas y compositores participaron a través de su labor en la gran dialéctica — muchas veces convulsa- de la época: tradición-modernidad.

En el ámbito conservador, se mostró un respeto firme por los usos heredados. Los poetas desarrollaron sus discursos a partir del modernismo (con las deudas decimonónicas simbolistas, parnasianas o románticas), de un realismo de corte regeneracionista, o bien de un tradicionalismo que podía caer en lo casticista, y siempre, todos, mostrando una continuidad ortodoxa por la tradición y sus recursos formales (estrofas, léxico, pautas métricas...). Los compositores preservaron en sus discursos el uso de la tonalidad y los comportamientos melódicos y armónicos consideraros canónicos. Unos y otros, también se sirvieron de las formas avaladas por la historia artística. Frente al conservadurismo, su antítesis más radical sería una postura abiertamente rupturista. En poesía encontramos múltiples ejemplos de esta tendencia, unas veces al amparo de vanguardias oficiales y otras, como en el caso de Lorca, absolutamente individuales. En el campo de la música española, sin embargo, la subversión rupturista apenas se dio salvo en eventuales y mínimos casos de atonalidad. Y, entre tradición y ruptura, una corriente progresista trató de hacer avanzar la creación en ambas disciplinas, con un ojo puesto en lo heredado y otro en la renovación. Los músicos y poetas progresistas, sin renunciar a formas tradicionales, intentaron, por un lado, suprimir de los discursos aquello que consideraron superfluo, sentimental o excesivamente anecdótico; para ello, trazaron una depuración de sus respectivos lenguajes mediante aparente sencillez y orden bien cincelado, sin aspavientos ni histrionismos, pero tampoco dando posibilidad de entrada a lo irracional. Junto a esta vía purificadora, cupo también otra mucho más violenta, «impura», llena de imágenes arriesgadas y elementos disonantes. $\mathrm{Ni}$ «puros» ni «impuros» llegaron a romper totalmente los vínculos con la herencia artística, aunque llevaran sus elementos hasta los límites (la tonalidad y la armonía en el caso de los compositores, las visiones sorprendentes en el de muchos poetas). La música y la poesía progresistas demostraron, por lo tanto, actitudes más de evolución que de revolución. Su postura, a medio camino de tradición y modernidad, fue difícil de defender, y posibilitó su heterogeneidad de manifestaciones. En una de ellas, la recuperación de material histórico y popular, demostraron claramente su alejamiento de la perspectiva conservadora, puesto que tiñeron el patrimonio cultural con elementos propios de la modernidad.

Por último, no podemos olvidar que la expresión trascendental, sea más conservadora o más moderna, adquiriere rasgos propios de una disciplina artística que puede combinarse con otra por medio de la colaboración. En la España de la época, la asociación entre poetas y compositores fue tan frecuente como en cualquier otro periodo histórico, aunque por la variedad de perspectivas y vías coincidentes en aquellas décadas, no es extraño que los vínculos eventuales 
se pudieran efectuar entre sensibilidades diferentes (recordemos que los libretos de obras de Falla tan importantes para el progresismo musical como El amor brujo o El sombrero de tres picos fueron escritos por una autora de sensibilidad tradicional como María Lejárraga).

Sin embargo, más allá de las colaboraciones interdisciplinares, lo más importante es observar cómo la intensa dialéctica de aquellos años, caracterizada por el debate entre tradición y novedad, incidió de manera tan semejante en la expresión articulada y en la no articulada. Sale a la luz, de esta manera, lo que realmente subyace entre poesía y música desde los tiempos primitivos, por mucho que la práctica parezca seguir caminos diferenciados: la profunda hermandad de ambos lenguajes.

\section{BIBLIOGRAFÍA}

Alberti, A. (1988): Obras completas (Tomo I: Poesía 1920-193). Madrid: Aguilar.

Alonso, D. (1962): Cuatro poetas españoles: (Garcilaso, Góngora, Maragall, Antonio Machado). Madrid: Gredos.

Barricelli, J. P. (1988): Melopoiesis: Approaches to the Study of Literature and Music. New York: New York University Press.

Bretón, T. (1920). Cuarteto en Re. Madrid: Sociedad Anónima Casa Dotesio.

Brown, C. S. (1963): Music and Literature. A Comparison of the Arts. Athens: The University of Georgia Press.

CANo Ballesta, J. (1972). La poesía española entre pureza y revolución (1920-1936). Madrid: Gredos.

CARDWELL, R. A. (2008): Salvador Rueda, ¿primer modernista? Relaciones literarias finiseculares entre coloristas, raros y escritores perlinos, en VV. AA., Salvador Rueda y su época. Autores, géneros y tendencias: Actas del XVIII Congreso de Literatura Española Contemporánea, Málaga, Aedile, pp. 21-47.

Celma Valero, M. P. (1993): «El modernismo visto por sus contemporáneos: las encuestas en las revistas de la época», en Cardwell, R. A., Y MacGuirk, B. (eds.): ¿Qué es el modernismo?: Nueva encuesta, nuevas lecturas. Boulder, Colorado: Society of Spanish and Spanish-American studies, pp. 25-38.

CERnudA, L. (2006). Obras completas (I). Madrid: RBA

Charles, A. (2005): Dodecafonismo y serialismo en España: compositores y obras. Valencia: Rivera Editores.

Diego, G. (1995). El romancero de la novia . Madrid: Ayuntamiento.

Díez de Revenga, F. J. (1973): La métrica de los poetas del 27. Murcia: Universidad de Murcia.

Domínguez Caparrós, J. (2007). Diccionario de métrica española. Madrid: Alianza Editorial.

- (2014). Métrica española. Madrid: Universidad Nacional de Educación a Distancia.

Falla, M. De (1924). El amor brujo. Londres: J. and Chester.

García Gallardo, C. L., Martínez González, F., y Ruiz Hilillo, M. (2010). Los músicos del 27. Granada: Universidad de Granada.

García LorCa, F (1968): Obras completas. Madrid: Aguilar.

- (1987). Poeta en Nueva York. Madrid: Cátedra.

HalfFter, E. (1927). Danza de la gitana. París: Max Eschig.

Hernández, M. (2005). Antología poética (6. ${ }^{\mathrm{a}}$ ed.). Madrid: EDAF.

Kramer, L. (1984): Music and Poetry. Berkeley: University of California Press.

Luján AtienZa, Á. L. (2010). El estribillo y sus variantes en la poesía española del siglo XX: Notas sobre su caracterización y tipología. En Rhytmica: revista española de métrica comparada [en 
línea], n. ${ }^{\circ}$ 8, 2010, pp. 37-66 [consulta el 26 de Junio de 2015]. Recuperado en: http://e-spacio. uned.es/fez/eserv/bibliuned:revistaRHYTHMICA-2010-8-7010/Documento.pdf

Machado, A. (1973). Poesías completas. Madrid. Espasa-Calpe.

Marco, T (1998). Historia de la música española. 6. Siglo XX. Madrid: Alianza.

Mcluhan, M. (1962): The Gutenberg Galaxy: The Making of Typographic Man. Toronto: University of Toronto Press.

Mompou, F. (1920): Cants mágics. Madrid: Unión Musical Española.

Moreno Torroba, F. (1932). Luisa Fernanda. Madrid: Unión Musical Española.

Morgan, R. P. (1999): La música del siglo XX. Madrid: AKAL.

Navarro Tomás, T. (1995): Métrica española. Barcelona: Labor.

Navas Ruiz, R. (2010). El siglo XIX. Madrid: Visor Libros.

Nommick, Y. (2002), Manuel de Falla y la pedagogía de la composición: el influjo de su enseñanza sobre el Grupo de los Ocho de Madrid, en Suárez Pajares, J. (ed.): Música española entre dos guerras, 1914-1945. Granada: Archivo Manuel de Falla.

Olmo Iturriarte, A. D. y Díaz de Castro, F. J. (2008): Introducción crítica. En: Olmo Iturriarte, A. D. y Díaz de Castro, F. J. (eds.), Antología de la poesía modernista española. Madrid: Castalia, pp. 7-31.

Paraíso, I. (1985). El verso libre hispánico: Orígenes y corrientes. Madrid: Gredos.

Paz, O. (1974). Los hijos del limo: Del romanticismo a la vanguardia. Barcelona: Seix Barral.

Rivas Hernández, A. (2008): Las ideas poéticas de Juan Valera en los «Estudios Críticos«. En RILCE: Revista de Filología Hispánica [en línea], vol. 24, n. ${ }^{\circ}$ 1, 2008, pp. 136-146 [consulta el 1 de Julio de 2015]. Recuperado en: http://dadun.unav.edu/bitstream/10171/6942/1/10.\%20Rivas.pdf

Rueda, S. (1894): El ritmo: crítica contemporánea. Madrid: Tipografía de los Hijos de M. G. Hernández.

SÁNCHeZ de ANDrÉs, L. (2009). Música para un ideal: Pensamiento y actividad musical del krausismo e institucionalismo españoles (1854-1936). Madrid: Sociedad Española de Musicología.

Sanz Del Río, J. (1867), Racionalismo armónico, recogido en Jiménez Landi, A. (1996), Los orígenes de la Institución, en La institución Libre de Enseñanza y su ambiente, vol. I. Madrid: Editorial Complutense.

Schoenberg, A. (1914). Pierrot Lunaire. Viena: Universal Edition.

Tarasti, E. (1979): Myth and Music: a Semiotich Aproach to the Aesthetics of Myth in Music. The Hague: Mouton.

TuÑón DE LARA, M. (1970): Medio siglo de cultura española (1885-1936). Madrid: Editorial Tecnos. 
